\title{
SIFAT-SIFAT CAHAYA DALAM DISCOVERY LEARNING UNTUK MENINGKATKAN KETERAMPILAN PROSES SAINS
}

\author{
Silva Nadhifatul A'yun ${ }^{1)} \&$ Bambang Subali ${ }^{2)}$ \\ ${ }^{1)}$ SD Negeri Tambakroto Sayung Demak, Jalan Onggorawe - Mranggen Km 4 Tambakroto Sayung 59563 \\ ${ }^{2)}$ Prodi Dikdas PPs Universitas Negeri Semarang, Kelud Utara III Petompon Gajahmungkur Semarang 50237 \\ e-mail: silvaayun194@gmail.com, bambangfisika@mail.unnes.ac.id
}

\begin{abstract}
Characteristics of Light in Discovery Learning to Improve Science Process Skills. This study aims to determine the differences of science learning outcomes about the lights nature between the experimental class and control class, by involving the improvement of science skills of five grade students of Tambakroto State Elementary School. This type of research is quasi experimental design and research design using control group pretest and posttest. The instruments that was used are questions for cognitive understanding and observation sheets for science skills. Result showed that the average of experiment class learning result was 79,14 while control class only reached 66,54 which was analyzed by using t-test with $t_{\text {count }}=3.026>t_{\text {table }}=2,007$. This indicates that there is a difference in learning outcomes between the experimental class and the control class. The result of observation of science process skill in experimental class is obtained percentage of pre-action average that is $50 \%$ and at action $78,33 \%$ have increase of $(\langle\mathrm{g}=0,56\rangle)$ in medium category. The conclusion is that the discovery learning model can improve the skills of the science process.
\end{abstract}

Keywords: discovery learning, natural science learning outcome, science process skills

\begin{abstract}
Abstrak: Sifat-sifat Cahaya dalam Discovery Learning untuk Meningkatkan Keterampilan Proses Sains. Penelitian ini bertujuan untuk mengetahui perbedaan hasil belajar IPA materi sifat-sifat cahaya antara kelas eksperimen dan kelas kontrol, dengan melibatkan peningkatan keterampilan proses sains siswa kelas V SD Negeri Tambakroto. Jenis penelitian ini adalah penelitian eksperimen semu (quasy exsperimental design) dan desain penelitian menggunakan control group pretest and posttest. Instrumen yang digunakan berupa soal tes untuk pemahaman kognitif dan lembar observasi untuk keterampilan proses sains. Hasil penelitian menunjukkan rata-rata hasil belajar kelas eksperimen adalah 79,14 sedangkan kelas kontrol hanya mencapai 66,54 yang dianalisis menggunakan uji-t dengan perolehan $t_{\text {hitung }}$ $=3,026>t_{\text {tabel }}=2,007$. Hal ini menunjukkan bahwa terdapat perbedaan hasil belajar antara kelas eksperimen dengan kelas kontrol. Adapun hasil observasi keterampilan proses sains pada kelas eksperimen diperoleh presentase rata-rata pra tindakan yaitu 50\% dan pada saat tindakan sebesar 78,33\% mengalami peningkatan sebesar $(<\mathrm{g}=0,56>)$ dalam kategori sedang. Jadi dapat disimpulkan bahwa model discovery learning dapat meningkatkan keterampilan proses sains.
\end{abstract}

Kata kunci: discovery learning, hasil belajar IPA, keterampilan proses sains

Ilmu Pengetahuan Alam (IPA) merupakan salah satu mata pelajaran wajib yang termuat dalam kurikulum SD. Menurut Susanto (2013: 167) sains atau IPA adalah usaha manusia dalam memahami alam semesta melalui pengamatan yang tepat sasaran, serta menggunakan prosedur dan dijelaskan dengan penalaran sehingga mendapat suatu kesimpulan. Proses pembelajaran IPA di SD menuntut guru untuk sekreatif mungkin supaya dapat menyampaikan materi secara detail sesuai dengan konsep pembela- jaran IPA yang tidak hanya melalui ceramah namun juga harus melibatkan partisipasi siswa secara aktif.

Namun pada kenyataannya kebanyakan pembelajaran masih bersifat teacher center dimana guru yang masih mendominasi pembelajaran di dalam kelas, sehingga siswa kurang terlibat secara aktif dalam proses pembelajaran. Berdasarkan hasil wawancara dengan guru kelas VA dan VB SD Negeri Tambakroto menyatakan bahwa proses pembelajar- 
an IPA dominan menggunakan ceramah dan pemberian tugas. Keterlibatan siswa secara aktif dalam pembelajaran cenderung tidak tampak karena pembelajaran hanya berpusat pada guru. Hal ini menyebabkan rendahnya hasil belajar siswa. Dari data Ulangan Akhir Semester (UAS) pada mata pelajaran IPA menunjukkan hasil yang kurang memuaskan dengan banyaknya siswa yang tidak mencapai nilai KKM (Kriteria Ketuntasan Minimal) yaitu 67. Kelas VA terdapat 5 siswa yang tuntas dengan presentase $17,24 \%$ dan siswa yang tidak tuntas sebanyak 24 siswa dengan presentase $82,75 \%$ dengan rata-rata 58,90, sedangkan pada kelas VB terdapat 3 siswa yang tuntas dengan presentase $11,53 \%$ dan sebanyak 23 siswa tidak tuntas dengan presentase $88,46 \%$ dengan rata-rata 61,73 .

Penyebab utama kelemahan pembelajaran tersebut adalah kebanyakan guru tidak melakukan kegiatan pembelajaran dengan memfokuskan pada pengembangan keterampilan proses sains anak. Hal inilah yang menyebabkan kegiatan pembelajaran dilakukan hanya terpusat pada penyampaian materi dalam buku teks saja. Padahal seharusnya siswa turut serta dalam mengembangkan keterampilan proses yang dimilikinya sehingga meningkatkan kemampuan berpikirnya.

Pembelajaran IPA di sekolah dasar hendaknya memperhatikan seluruh komponen-komponen yang terkandung dalam IPA agar sesuai dengan fungsi dalam pembelajaran IPA salah satunya yaitu dengan mengembangkan dimensi proses yakni keterampilan proses sains. Menurut Susanto (2013: 169) keterampilan proses sains (science process skills) adalah keterampilan yang dilakukan oleh para ilmuwan seperti mengamati, mengukur, mengklasifikasi, menyimpulkan dan mengomunikasikan.

Keterampilan proses sains dapat dipelajari oleh para siswa sekolah dasar dalam bentuk yang lebih sederhana sesuai tahap perkembangan anak usia sekolah dasar. Tahap berpikir anak usia SD menurut Piaget telah mencapai taraf berpikir induktif, yakni berpikir dari hal-hal konkret ke abstrak, dan dari sederhana ke kompleks.

Keterampilan proses sains dapat dikembangkan apabila siswa aktif dalam pembelajaran. Siswa dikondisikan membaca sendiri, mengaitkan konsepkonsep baru dengan berdiskusi dan menggunakan istilah, konsep dan prinsip baru melalui serangkaian aktivitas belajar (Aji, 2015: 2)

Keterampilam proses sains luas dan meyeluruh, mulai dari mengamati, mengukur, mengklasifikasi, menyimpulkan dan mengomunikasikan. Sehingga perlu difokuskan pada keterampilan mengamati, keterampilan mengklasifikasikan dan keterampilan mengomunikasikan. Menurut Bundu (2006: 25) keterampilan mengamati merupakan proses IPA yang terpenting karena kebenaran ilmu yang diperoleh bergantung pada kebenaran dan kecermatan hasil observasi. Keterampilan mengklasifikasikan merupakan kemampuan untuk mencari perbedaan, mengontraskan, mencari kesamaan, membandingkan dan mencari dasar penggolongan. Dan keterampilan mengomunikasikan merupakan kemampuan untuk menyampaikan hasil pengamatan atau pengetahuan yang dimiliki kepada orang lain, baik secara lisan maupun tulisan.

Selain memperhatikan keterampilan proses sains pada siswa, untuk memperbaiki proses pembelajaran IPA dapat dilihat dari seberapa baik pengkondisian kelas dalam menciptakan dan mengembangkan suasana belajar. Salah satu cara untuk mewujudkan hal tersebut adalah dengan memposisikan siswa sebagai bagian penting dalam menemukan dan memproses bahan belajarnya sendiri.

Penerapan model discovery learning dapat dijadikan sebagai salah satu alternatif untuk mengatasi permasalahan diatas. Menurut Kristin dan Rahayu (2016: 86) pembelajaran discovery learning adalah suatu model untuk mengembangkan cara belajar siswa aktif dengan menemukan sendiri, menyelidiki sendiri maka hasil yang diperoleh akan setia dan tahan lama dalam ingatan, tidak akan mudah dilupakan oleh siswa. Dengan belajar penemuan, anak juga bisa berpikir lebih kritis dan mampu memecahkan masalah sendiri yang dihadapi.

Jerome Bruner pertama kali mengembangkan model pembelajaran discovery learning. Menurut Bruner bahwa belajar penemuan (discovery learning) sesuai dengan pencarian pengetahuan secara aktif oleh manusia sehingga dengan sendirinya memberikan hasil yang paling baik. Lebih lanjut Bruner mengatakan agar siswa hendaknya dalam belajar berpartisipasi aktif untuk menemukan konsep-konsep dan prinsip-prinsip serta mereka dianjurkan untuk memperoleh pengalaman dan melakukan eksperimen-eksperimen yang mengijinkan mereka untuk menemukan konsep dan prinsip itu sendiri $(\mathrm{Mu}-$ barok \& Sulistyo, 2014: 216)

Hasil penelitian dari Lete et al. (2016) menunjukkan bahwa terjadi peningkatan keterampilan proses IPA pada siswa dengan penggunaan model pembelajaran discovery learning. Sehingga model discovery learning mempunyai pengaruh yang signifikan terhadap keterampilan proses IPA pada siswa. Berdasarkan permasalahan tersebut, maka dilakukan penelitian ini dengan tujuan untuk mengetahui perbedaan hasil belajar IPA materi sifatsifat cahaya antara kelompok siswa yang mengikuti 
pembelajaran menggunakan model discovery learning dengan model konvensional, dan dengan melibatkan peningkatan keterampilan proses sains pada siswa kelas V SD Negeri Tambakroto.

\section{METODE}

Penelitian ini dilakukan di SD Negeri Tambakroto Sayung Demak Semester 1 Tahun Pelajaran 2017/2018. Populasi dalam penelitian ini adalah seluruh siswa kelas $\mathrm{V}$ yang berjumlah 55, yang terdiri dari kelas VA sebanyak 29 siswa dan kelas VB sebanyak 26 siswa. Penentuan jumlah sampel berdasarkan populasi yang ada dilakukan dengan teknik sampling jenuh yaitu seluruh siswa kelas V SD Tambakroto. Penarikan sampel dalam penelitian ini menggunakan random sampling. Penarikan sampel teknik random sampling ini digunakan untuk menentukan kelas kontrol dan kelas eksperimen. Berdasarkan hasil uji kesetaraan yang telah dilakukan, didapatkan hasil bahwa seluruh siswa kelas V SD Tambakroto memiliki kemampuan yang setara. Untuk menentukan kelas eksperimen dan kontrol, peneliti melakukan pengundian. Dalam proses pengundian tersebut diperoleh kelas VA sebagai kelas eksperimen yang nantinya diberikan perlakuan menggunakan model discovery learning. Dan kelas VB sebagai kelas kontrol yang menggunakan pembelajaran konvensional.

Penelitian ini termasuk jenis penelitian eksperimen. Lebih tepatnya menggunakan metode kuantitatif dengan pendekatan quasi exsperimental design dan desain penelitian menggunakan control group pretest and posttest, dimana kondisi awal kedua sampel diberikan pretest, setelah itu kelas eksperimen mendapat perlakuan model discovery learning dan kelas kontrol menggunakan pembelajaran konvensional. Kemudian selanjutnya diberikan posttest untuk mengetahui hasil belajar siswa setelah diberi perlakuan dan untuk mengetahui peningkatan keterampilan proses sains siswa.

Data penelitian ini berupa hasil belajar dan keterampilan proses sains siswa. Teknik pengumpulan data dalam penelitian ini menggunakan teknik tes dan nontes. Teknik tes digunakan untuk mengukur hasil belajar siswa yang diukur menggunakan tes evaluasi. Dan teknik nontes digunakan untuk mengukur keterampilan proses sains yang diamati menggunakan lembar observasi.

Analisis data yang digunakan dalam penelitian ini adalah uji-t untuk sampel independen (independent sample t-test). Analisis digunakan untuk mengetahui signifikan perbedaan antara kelas kontrol dan eksperimen sebelum dan sesudah perlakuan.
Uji-t dilakukan setelah dilakukan uji prasyarat yaitu uji normalitas dan uji homogenitas.

Aspek utama yang dijadikan penilaian adalah peningkatan hasil belajar dan peningkatan keterampilan proses sains yang ditunjukkan dengan hasil pretest dan posttest. Peningkatan ini dihitung menggunakan gain ternormalisasi antara nilai pretest dan posttest.

\section{HASIL DAN PEMBAHASAN}

Proses pembelajaran pada kelas eksperimen dilakukan mengunakan model discovery learning, sedangkan pada kelas kontrol proses pembelajaran menggunakan model konvensional dimana guru hanya menyampaikan materi dengan metode ceramah (teacher center). Pada awal pembelajaran, kedua kelas diberikan soal pretest terlebih dahulu.

Selanjutnya data kedua kelas dianalisis menggunakan uji normalitas dan homogenitas. Jika distribusi data didapatkan homogen maka pemilihan sampel untuk kelas eksperimen dan kelas kontrol dilakukan dengan teknik random sampling. Berdasarkan hasil uji normalitas didapatkan nilai $\mathrm{L}_{\text {maks }}$ pada kelas eksperimen adalah 0,07 dan $\mathrm{L}_{\text {maks }}$ pada kelas kontrol adalah 0,10. Sehingga dapat disimpulkan $\mathrm{L}_{\text {maks }}<\mathrm{L}_{\text {tabel }}$ pada $\alpha 5 \%$. Hal ini menunjukkan bahwa sampel berasal dari populasi yang berdistribusi normal. Dan berdasarkan hasil uji homogenitas diperoleh $\mathrm{F}_{\text {hitung }}=1,07 \mathrm{~F}_{\text {tabel }}=1,93$ pada $\alpha$ $5 \%$ sehingga dapat disimpulkan bahwa sampel penelitian berasal dari kondisi yang sama (homogen) karena $F_{\text {hitung }}<F_{\text {tabel }}(1,07<1,93)$. Sehingga diperoleh kelas VA sebagai kelas eksperimen yang nantinya diberikan perlakuan menggunakan model discovery learning. Dan kelas VB sebagai kelas kontrol yang menggunakan model pembelajaran konvensional.

Pembelajaran pada kelas eksperimen diterapkan dengan mengawali pembelajaran dengan menggunakan pemberian gambaran atau simulation fenomena dalam kehidupan sehari-hari mengenai sifat-sifat cahaya misal dari cahaya senter, cahaya lampu motor dll. Siswa selanjutnya mencari permasalahan berkaitan dengan materi tersebut (problem statement). Tahapan selanjutnya yaitu mengumpulkan data-data (collecting data) melalui membaca buku, mengamati fenomena yang terjadi disekitar ataupun melakukan uji coba sendiri. Setelah melakukan percobaan, siswa aktif berdiskusi dengan kelompoknya untuk memahami konsep IPA mengenai materi sifat-sifat cahaya (processing data). Siswa selanjutnya melakukan pemeriksaan (verification) secara cermat untuk membuktikan benar 
tidaknya hipotesis yang ditetapkan diawal dengan dihubungkan dengan hasil pengolahan data. Tahapan terakhir yaitu siswa menarik kesimpulan (generalization) mengenai hasil percobaan yang telah dilakukan untuk dapat dijadikan prinsip umum dan berlaku untuk semua kejadian atau masalah yang sama (Syah dalam Hosnan, 2014: 289-291).

Berdasarkan hasil perhitungan t-test setelah dilakukannya perlakuan diperoleh bahwa $t_{\text {hitung }}$ sebesar 3,026 dan $t_{\text {tabel }} 2,007$ pada $\alpha 5 \%$. Berdasarkan perolehan tersebut tampak bahwa $t_{\text {hitung }}>t_{\text {tabel }}$ (3,026> 2,007), sehingga $H_{a}$ diterima. Dari hal tersebut dapat disimpulkan bahwa terdapat perbedaan hasil belajar antara kelas eksperimen dengan kelas kontrol. Perbedaan tersebut menunjukkan adanya pengaruh model discovery learning terhadap hasil belajar IPA siswa kelas V. Hal tersebut diperkuat dengan grafik berikut ini:

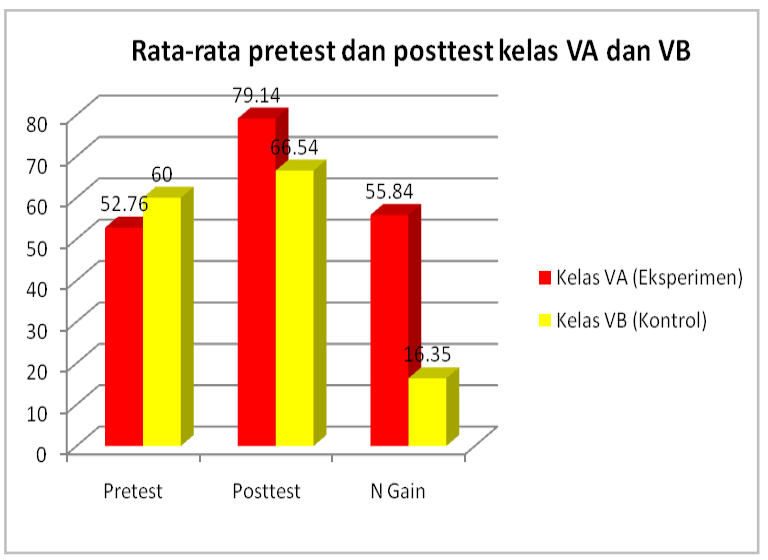

\section{Gambar 1. Grafik rata-rata pretest dan posttest kelas VA dan VB}

Grafik diatas menunjukkan bahwa kelas eksperimen mengalami peningkatan rata-rata hasil belajar lebih tinggi dibanding kelas kontrol. Kelas eksperimen mengalami peningkatan sebesar $(<\mathrm{g}=0,56>)$ dengan kategori sedang, sedangkan kelas kontrol hanya mengalami peningkatan sebesar $(<\mathrm{g}=0,16\rangle)$ dengan kategori rendah.

Hasil belajar siswa sesudah pembelajaran menggunakan model discovery learning lebih baik dari sebelumnya, seperti yang terlihat pada grafik 1. Ratarata nilai kelas eksperimen lebih tinggi dibanding rata-rata nilai pada kelas kontrol. Hal ini dikarenakan pada kelas eksperimen dengan melakukan kegiatan praktikum melibatkan siswa secara langsung dalam menyampaikan ide-ide dari mulai membuat hipotesis sampai tahap menarik kesimpulan jadi pembelajaran berpusat pada siswa (studentcentered learning) sehingga dapat terbangun sikap aktif, kreatif dan inovatif dalam diri siswa. Guru hanya sebagai fasilitator, guru membimbing siswa agar mereka menemukan pengetahuannya sendiri.

Hal ini sesuai dengan pendapat Syafi'i et al. (2014: 13) yang menyatakan bahwa peningkatan hasil belajar kognitif dikarenakan question based discovery learning menggunakan prinsip kerja berpikir kritis dan melakukan sendiri. Kegiatan memecahkan masalah secara mandiri yang tersaji dalam lembar diskusi dapat meningkatkan pemahaman dan daya ingat siswa.

Menurut Susanto (2013: 169) ada 5 keterampilan proses sains seperti mengamati, mengukur, mengklasifikasi, menyimpulkan dan mengomunikasikan. Namun penelitian ini hanya fokus mengamati 3 aspek dalam keterampilan proses IPA yaitu mengamati, mengklasifikasikan dan mengomunikasikan. Data keterampilan proses sains pada materi sifat-sifat cahaya menekankan pada aspek psikomotor siswa pada kelas eksperimen yang diukur menggunakan lembar observasi. Penilaian keterampilan proses diambil saat pelaksanaan pembelajaran, diskusi dan eksperimen. Praktikum dilaksanakan dengan menggunakan alat dan bahan yang telah dipersiapkan sebelumnya.

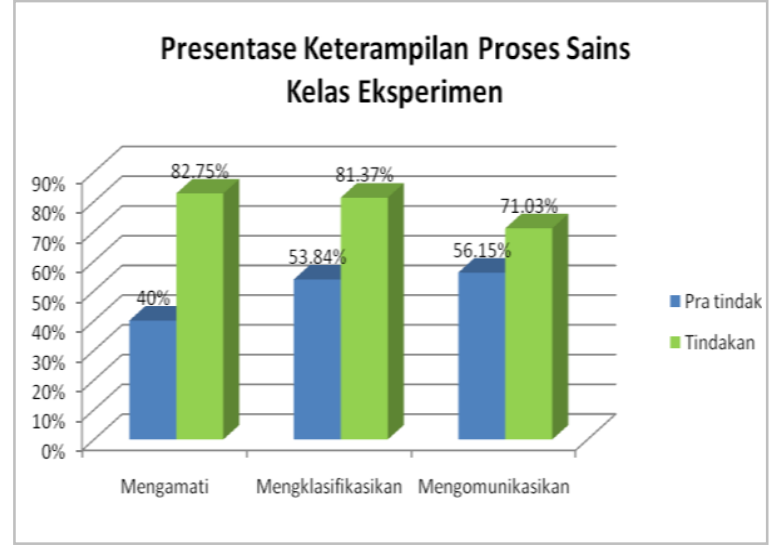

\section{Gambar 2. Grafik Presentase Keterampilan Proses Sains Kelas Eksperimen}

Berdasarkan grafik diatas dapat diketahui bahwa aspek mengamati sebelum tindakan yaitu sebesar $40 \%$ dalam kategori cukup rendah karena siswa belum terbiasa melakukan praktikum dengan mengamati suatu objek atau fenomena-fenomena tertentu. Namun pada saat perlakuan dengan model discovery learning aspek mengamati siswa meningkat menjadi 82,75\% dengan kategori sangat tinggi.

Pada aspek mengklasifikasikan sebelum tindakan yaitu diperoleh presentase 53,84\% dalam kategori sedang. Kemudian setelah menggunakan model discovery learning aspek mengklasifikasikan meningkat menjadi $81,37 \%$ dalam kategori sangat 
tinggi. Hal tersebut dikarenakan dalam model discovery learning terdapat tahap verifikasi dimana siswa membuktikan hipotesisnya dengan mengklasifikasikan hasil temuannya dihungkan dengan hipotesis awal.

Mengomunikasikan hasil eksperimen yaitu mengomunikasikan hasil secara tulisan melalui laporan dan mengomunikasikan secara lisan melalui presentasi. Pra tindakan diperoleh presentase 56,15\% dengan kategori sedang. Keberhasilan siswa dalam membuat laporan sudah termasuk baik namun ketika melakukan presentasi masih tergolong kurang. Kurangnya keberhasilan siswa dalam melakukan presentasi karena keterbatasan waktu pertemuan sehingga kesempata belajar siswa untuk maju mempresentasikan hasil eksperimen terbatas dan disebabkan karena kurangnya rasa percaya diri siswa. Hal tersebut sesuai dengan penelitian Marnita (2013) yang menyatakan bahwa kebanyakan peserta didik belum memiliki rasa percaya diri untuk menyampaikan hasil temuan eksperimennya. Kemudian meningkat pada saat menggunakan model discovery learning menjadi $71,03 \%$ dalam kategori tinggi

Hasil observasi keterampilan proses sains pada kelas eksperimen diperoleh presentase rata-rata pra tindakan yaitu 50\% dan pada saat tindakan sebesar $78,33 \%$ mengalami peningkatan sebesar $(<\mathrm{g}=0,56$

\section{DAFTAR RUJUKAN}

Aji, F.P. 2015. Perbedaan Keterampilan Proses IPA Siswa pada Pembelajaran menggunakan Pendekatan Saintifik dan STM. Jurnal Pendidikan Guru Sekolah Dasar, 4 (6): 1-10.

Bundu, P. 2016. Penilaian Keterampilan Proses dan Sikap Ilmiah dalam Pembelajaran Sains SD. Jakarta: Depdikdas

Hosnan. 2014. Pendekatan Saintifik dan Kontekstual dalam Pembelajaran Abad 21. Bogor: Ghalia Indonesia

Ilmi, A.N.A., Indrowati, M., \& Probosari, R.M. 2012. Pengaruh Penerapan Metode Pembelajaran Guided Discovery terhadap Keterampilan Proses Sains Siswa Kelas X SMA Negeri 1 Teras Boyolali. Jurnal Pendidikan Biologi, 4 (2): 44-52.

Kristin, F. \& Rayahu, D. 2016. Pengaruh Penerapan Model Pembelajaran Discovery Learning terhadap Hasil Belajar IPS pada siswa kelas 4 SD. SCHOLARIA: Jurnal Pendidikan dan Kebudayaan, 6 (2): 84-92.

Lete, M., Sutopo, \& Yuliati, L. 2016. Peningkatan Keterampilan Proses Sains Siswa melalui Pem
>) dalam kategori sedang. Sehingga dapat disimpulkan bahwa model discovery learning dapat meningkatkan keterampilan proses sains.

Hal tersebut sesuai dengan hasil penelitian Ilmi et al. (2012) yang menyatakan bahwa model discovery learning dapat meningkatkan keterampilan sains dikarenakan dalam model tersebut terdapat tahapan-tahapan yang mendukung aspek keterampilan proses sains seperti pemberian rangsangan, identifikasi masalah, mengumpulkan data, mengolah data, verifikasi sampai pada tahapan menarik kesimpulan. Pembelajaran IPA menggunakan model discovery learning sudah sesuai dengan hakikat sains yang mengutamakan aspek proses dan produk.

\section{SIMPULAN}

Hasil penelitian menunjukkan bahwa terdapat perbedaan hasil belajar antara kelas eksperimen dengan kelas kontrol. Perbedaan tersebut menunjukkan adanya pengaruh model discovery learning terhadap hasil belajar IPA. Dan penerapan model discovery learning dalam proses pembelajaran dapat meningkatkan keterampilan proses sains. Peningkatan hasil belajar dan keterampilan proses sains siswa dalam kategori sedang.

belajaran Discovery Topik Tekanan Hidrostatis. Prosiding Seminar Nasional Pendidikan IPA Pascasarjana UM, Volume 1: 1020-1032.

Marnita. 2013. Peningkatan Keterampilan Proses Sains melalui Pembelajaran Kontekstual pada Mahasiswa Semester 1 Materi Dinamika. Jurnal Pendidikan Fisika Indonesia, 9: 43-52.

Mubarok, C. \& Sulistyo, E. 2014. Penerapan Model Pembelajaran Discovery Learning terhadap Hasil Belajar Siswa kelas X TAV pada Standar Kompetensi Melakukan Instalasi Sound System di SMK Negeri 2 Surabaya. Jurnal Pendidikan Teknik Elektro, 3 (2): 215-221.

Susanto, A. 2013. Teori Belajar \& Pembelajaran di Sekolah Dasar. Jakarta: Kencana Prenada Media Group.

Syafi'i, A., Handayani, L., \& Khanafiyah, S. 2014. Penerapan Question Based Discovery Learning pada Kegiatan Laboratorium Fisika untuk Meningkatkan Keterampilan Proses Sains. Unnes Physic Education Journal, 3 (2): 10-17. 